\title{
UPAYA MENINGKATKAN HASIL BELAJAR BAHASA INGGRIS MELALUI MODEL PEMBELAJARAN E- LEARNING DI SD YABES SCHOOL
}

\author{
Buce Gery sixson ${ }^{1}$, Megaria Purba ${ }^{2}$, Marice Saragih ${ }^{3}$ \\ AMIK Widyaloka- Management Informatika Komputer \\ Jl. Matahari Raya No. 2 Medan \\ gerysix@gmail.com, megariapurba18@gmail.com, maricesaragih79@gmail.com
}

\begin{abstract}
Abstrak
Pembelajaran daring pada Era New Normal diharapkan untuk meningkakan kuantitas dan kualitas sumber daya manusia yang mempunyai potensi intelegensi untuk menghadapi abad ke-21. Sehingga pembelajaran dengan menggunakan e-learning sangat efektif dilakukan untuk pencapaian tujuan pembelajaran. Tujuan dari pada penelitian ini adalah untuk menemukan peningkatan hasil belajar bahasa Inggris Siswa dengan menggunakan model pembelajaran E-Learning. Metode yang digunakan dalam penelitian ini adalah metode kuantitatif, yang mana dalam melihat hasil penelitian ini dibagi dalam dua kelas, satu kelas adalah untuk kontrol group dan satu kelas untuk experimental kelas masing-masing kelas di adakan pre-test dan post test.

Dalam penelitian ini ditemukan siswa sangat bersemangat dan antusias untuk mengikuti pembelajaran dengan menggunakan E-learning, seluruh siswa aktif dalam pembelajaran dan aktif mengerjakan latihan yang telah diberikan oleh dosen. Dengan adanya penerapan model pembelajaran E-Leraning tersebut siswa dapat lebih aktif belajar dan dapat meningkatkan hasil belajar siswa. Di kelas experimental nilai yang terendah di dalam pre-test adalah 35 dan yang tertinggi adalah 71, sementara nilai yang terendah di dalam post-test adalah 63 dan nilai yang tertinggi adalah 88 . Nilai rata-rata dari pre-test adalah $(53,40)$ dan post test ( 76.00). jadi deviasi adalah 22,6. Dari tabel 2 diatas dapat di lihat bahwa dalam kelas kontrol, skore yang terrendah dalam pre-test adalah 34 dan skor yang tertinggi adalah 72 . Sementara peningkatan rata-rata nilai dari pre test $(48,66)$ to post-test $(55.33)$. Dari hasil diatas dapat disimpulkan bahwa ada peningkatan hasil belajar bahasa Inggris siswa ketika diterapkan model pembelajarn ELearning.
\end{abstract}

\section{Kata-kata kunci: Peningkatan, Hasil Belajar, E-learning.}

\section{PENDAHULUAN}

Dampak covid-19 terhadap pendidikan sangatlah berpengaruh terhadap kualitas sumber daya manusia. Pemerintah melalui Kementerian pendidikan dan Kebudayaan mengeluarkan Peraturan untuk mengadakan pembelajaran secara daring. Sehingga upaya kampus Widyaloka untuk memutuskan rantai pandemi Covid 19 hingga perkuliahan dilakukan dengan daring yaitu dengan menggunakan E-learning dan Video Conference baik itu zoom cloud meeting, geogle meet. E-learning merupakan salah satu 


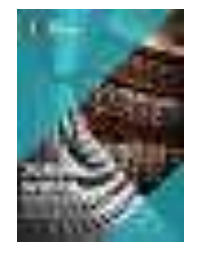

bentuk model pembelajaran yang difasilitasi dan didukung pemanfaatan teknologi informasi dan komunikasi. E-learning mempunyai ciri- ciri, antara lain (Clark \& Mayer 2008: 10): 1) memiliki konten yang relevan dengan tujuan pembelajaran; 2) menggunakan metode instruksional, misalnya penyajian contoh dan latihan untuk meningkatkan pembelajaran; 3) menggunakan elemen-elemen media seperti kata-kata dan gambar-gambar untuk menyampaikan materi pembelajaran; 4) memungkinkan pembelajaran langsung berpusat pada pengajar (synchronous e-learning) atau di desain untuk pembelajaran mandiri (asynchronous e-learning); 5) membangun pemahaman dan keterampilan yang terkait dengan tujuan pembelajaran baik secara perseorangan atau meningkatkan kinerja. Berdasarkan statement diatas pembelajaran dengan menggunakan E-learning sangat efektif saat era new normal, dikarenakan aspek-aspek yang mencakup dalam model E- learning udah dipahami oleh siswa. Seok (2008:725) menyatakan bahwa "e-learning is a new form of pedagogy for learning in the 21st century. $e$ Teacher are elearning instructional designer, facilitator of interaction, and subject matter experts".Dengan adanya media yang menarik akan dapat merangsang pikiran, perasaan, perhatian dan minat siswa dalam mengikuti pembelajaran dan termotivasi dalam pembelajaran dan salah satunya media yang sangat menarik saat ini adalah media E-Learning.

Penggunaan Web E-Learning dapat diasumsikan sebagai salah satu faktor pendorong berkembangnya proses pembelajaran jarak jauh yang mana seorang pengajar dituntut paham menerapkan teknologi komputer berbasis jaringan (network) dalam proses pembelajaran. Dengan adanya penggunaan E-learning dalam proses belajar mengajar membuat peserta didik lebih tertarik dalam mengikuti pelajaran dan membuat peserta didik lebih aktif dalam memperoleh informasi dibanding hanya memberikan tugas hanya melalui wa group. Penerapan pembelajaran online dengan menggunakan E-learning untuk pembelajaran saat era New normal sangatlah mudah dengan memanfaatkan modul learning management sistem. Beberapa prinsip membuat situs pembelajaran atau website e-learning menurut Munir (2009: 191) antara lain:

1. Merumuskan tujuan pembelajaran;

2. Mengenalkan materi pembelajaran memberikan bantuan dan kemudahan bagi pembelajar untuk mempelajari materi pembelajaran;

3. Memberikan bantuan dan kemudahan bagi pembelajar untuk mengerjakan tugas-tugas dengan perintah dan arahan yang jelas;

4. Materi pembelajaran yang disampaikan sesuai standar yang berlaku secara umum, serta sesuai dengan tingkat perkembangan pembelajar;

5. Materi pembelajaran disampaikan dengan sistematis dan mampu memberikan motivasi belajar, serta pada bagian akhir setiap materi pembelajaran dibuat rangkumannya;

6. Materi pembelajaran disampaikan sesuai dengan kenyataan, sehingga mudah di pahami, diserap, dan dipraktekkan langsung oleh pembelajar;

7. Metode penjelasannya efektif, jelas, dan mudah dipahami oleh pembelajar dengan disertai ilustrasi, contoh dan demonstrasi; Sebagai alat untuk mengetahui keberhasilan pembelajaran, maka dapat dilakukan evaluasi dan meminta umpan balik (feedback) dari pembelajar.

Di era new normal saat ini seorang pengajar harus menguasai suatu teknologi sehingga anak yang di ajar tidak ketinggalan informasi, dengan adanya pengetahuan mengenai teknologi informasi internet akan memudahkan seorang guru dalam memberikan materi dalam proses belajar mengajar. 
Evalusi pembelajaran dalam sistem e- learning dapat dilakukan secara langsung, sehingga siswa dapat mengetahui hasil dari mengerjakan latihan dan tugas yang diberikan oleh wali kelas

Rusman, dkk (2011:42) mengatakan bahwa Kegiatan evaluasi pelaksanaan pembelajaran $e$ learning dapat dilihat dari segi peningkatan pengetahuan dan keterampilan, lingkungan belajar, dan pengaruhnya. Evaluasi pelaksanaan e-learning merupakan proses menganalisis kualitas proses pembelajaran berbasis web (e-learning) dan sejauh mana ketercapaian dari proses e-learning tersebut untuk dapat dirasakan para pembelajar. Pelaksanaan evaluasi dilakukan sebagai bentuk penilaian terhadap berbagai komponen yang terdapat pada e-learning.

Dengan adanya survey yang dilakukan peneliti dan menemukan bahwa di masa pandemi-19 ini banyak guru-guru hanya memberikan tugas-tugas yaitu hanya melalui WA group dan banyak guru-guru yang kurang memahami penggunaan E-Learning dalam proses belajar mengajar dengan demikian penulis tertarik untuk meneliti tentang apakah ada dampak dari model pembelajaran E-Learning terhadap peningkatan hasil belajar di Yabes School.

\section{METODE}

Metode penelitian yang dilakukan menggunakan metode penelitian kuantitatif yang mana variabel (X) adalah Model Pembelajaran E-Learning, dan Variabel (Y) adalah hasil belajar bahasa Inggris . Populasi dari pada penelitian ini adalah seluruh SD Yabes School yang berjumlah 170 siswa dan yang menjadi sample adalah siswa kelas 6 SD yang berjumlah 30 orang dan dibagi dalam 2 kelas , satu kelas untuk kelas kontrol dan satu kelas untuk kelas explerimental, yang mana kelas kontrol tidak diberi model pembelajaran dengan menggunakan E-Learning dan kelas Experimen diberi perlakuan dengan menggunakan E-Learning. Instrumen dan teknik yang digunakan dalam pengumpulan data pada penelitian ini adalah dengan memberikan Pre-test dan Post-Test terhadap kedua kelas,

\section{HASIL DAN PEMBAHASAN}

Dalam Penelitian ini penulis mengadakan pre-test dan post test pada kelas experimental dan kelas kontrol untuk melihat apakah ada peningkatan hasil belajar bahasa Inggris dengan menggunakan model pembelajaran E-Learning

Table.1. Hasil dari kelas Experimental

\begin{tabular}{|c|l|c|c|}
\hline NO & $\begin{array}{c}\text { Nama Inisial } \\
\text { Siswa }\end{array}$ & $\begin{array}{c}\text { PRE- } \\
\text { TEST } \\
(\mathrm{y} 1)\end{array}$ & $\begin{array}{c}\text { POST-TEST } \\
(\mathrm{y} 2)\end{array}$ \\
\hline 1 & AGN & 52 & 82 \\
\hline 2 & ALX & 71 & 79 \\
\hline 3 & ANDK & 54 & 70 \\
\hline 4 & ASM & 39 & 72 \\
\hline 5 & BHT & 61 & 82 \\
\hline 6 & DS & 60 & 78 \\
\hline 7 & DNA & 45 & 70 \\
\hline 8 & DWI & 40 & 75 \\
\hline
\end{tabular}


Volume 2, Nomor 1, April 2021: halaman 83-89

\begin{tabular}{|c|l|c|c|}
\hline 9 & ES & 65 & 82 \\
\hline 10 & FS & 68 & 88 \\
\hline 11 & GUM & 50 & 71 \\
\hline 12 & GAH & 65 & 79 \\
\hline 13 & IPS & 60 & 80 \\
\hline 14 & IBS & 36 & 68 \\
\hline 15 & JP & 35 & 63 \\
\hline & TOTAL & $\mathbf{8 0 1}$ & $\mathbf{1 1 3 9}$ \\
\hline & MEAN & $\mathbf{5 3 , 4}$ & $\mathbf{7 6 , 0 0}$ \\
\hline
\end{tabular}

Dari tabel diatas dapat dilihat bahwa di dalam kelas experimental nilai yang terrendah di dalam pre-test adalah 35 dan yang tertinggi adalah 71, sementara nilai yang terendah di dalam post-test adalah 63 dan nilai yang tertinggi adalah 88 . Nilai rata-rata dari pre-test adalah $(53,40)$ dan post test ( 76.00$)$. jadi deviasi adalah 22,6

Table 2 Hasil dari kelas Kontrol

\begin{tabular}{|c|l|c|c|}
\hline NO & $\begin{array}{c}\text { INISIAL } \\
\text { NAMA SISWA }\end{array}$ & $\begin{array}{c}\text { PRE-TEST } \\
(\mathrm{y} 1)\end{array}$ & $\begin{array}{c}\text { POST-TEST } \\
(\mathrm{y} 2)\end{array}$ \\
\hline 1 & AFS & 50 & 55 \\
\hline 2 & ACMS & 60 & 66 \\
\hline 3 & AFWS & 45 & 53 \\
\hline 4 & BS & 34 & 48 \\
\hline 5 & CUP & 45 & 45 \\
\hline 6 & CAS & 42 & 50 \\
\hline 7 & DMN & 47 & 52 \\
\hline 8 & EDS & 40 & 58 \\
\hline 9 & EN & 45 & 65 \\
\hline 10 & EMN & 65 & 66 \\
\hline 11 & FEB & 65 & 66 \\
\hline 12 & FSB & 60 & 65 \\
\hline 13 & GJP & 44 & 48 \\
\hline 14 & HDW & $\mathbf{7 3 0}$ & $\mathbf{8 3 0}$ \\
\hline 15 & INS & & $\mathbf{4 5 6}, \mathbf{6 3}$ \\
\hline & TOTAL & & \\
\hline & MEAN & & 51 \\
\hline & & 45 & 56 \\
\hline
\end{tabular}

\section{c) (1) (2)}

JURNAL WIDYA This work is licensed under a Creative Commons Attribution-NonCommercialShareAlike 4.0 International License. 
Dari tabel 2 diatas dapat di lihat bahwa dalam kelas kontrol, skore yang terrendah dalam pre-test adalah 34 dan skor yang tertinggi adalah 72 . Sementara peningkatan rata-rata nilai dari pre test $(48,66)$ to post-test (55.33)

\section{Analisis Data}

Penulis menerapkan E-Learning di dalam penelitian ini. E-learning adalah salah model pembelajaran yang difasilitasi dan didukung pemanfaatan teknologi informasi dan komunikasi dalam proses belajar mengajar. Dengan menerapkan E-Learning siswa akan lebih aktif dan tertarik dalam mengikuti pembelajaran bahasa Inggris.

Sebelum strategi ini dilaksanakan dalam experimental group penulis memberikan pre -test dan post test kepada kelas kontrol untuk melihat peningkatan siswa terhadap kemampuan bahasa Inggris. Hasil dari post-test yang di lakukan siswa dalam kelas experimental dapat di lihat dalam tabel berikut ini

Table 3. Kalkulasi dari kelas experimental

\begin{tabular}{|c|l|c|c|c|c|}
\hline NO & $\begin{array}{c}\text { STUDENTS' } \\
\text { INITIAL NAME }\end{array}$ & $\begin{array}{c}\text { PRE- } \\
\text { TEST } \\
(\mathrm{y} 1)\end{array}$ & $\begin{array}{c}\text { POST- } \\
\text { TEST } \\
(\mathrm{y} 2)\end{array}$ & $\begin{array}{c}\text { DEVIATIO } \\
\text { N } \\
(\mathrm{d})\end{array}$ & $\begin{array}{c}\text { Square } \\
\text { Deviation } \\
(\mathrm{dx})^{2}\end{array}$ \\
\hline 1 & AGN & 52 & 82 & 30 & 900 \\
\hline 2 & ALX & 71 & 79 & 8 & 64 \\
\hline 3 & ANDK & 54 & 70 & 16 & 256 \\
\hline 4 & ASM & 61 & 82 & 21 & 1089 \\
\hline 5 & BHT & 60 & 78 & 18 & 341 \\
\hline 6 & DS & 45 & 70 & 25 & 625 \\
\hline 7 & DNA & 40 & 75 & 35 & 1225 \\
\hline 8 & DWI & 65 & 82 & 17 & 289 \\
\hline 9 & ES & 68 & 88 & 20 & 400 \\
\hline 10 & FS & 50 & 71 & 21 & 441 \\
\hline 11 & GUM & 65 & 79 & 14 & 196 \\
\hline 12 & GAH & 60 & 80 & 20 & 400 \\
\hline 13 & IPS & 36 & 68 & 24 & 576 \\
\hline 14 & IBS & 35 & 63 & 28 & 784 \\
\hline 15 & JP & $\mathbf{8 0 1}$ & $\mathbf{1 1 3 9}$ & $\mathbf{3 3 0}$ & \\
\hline & TOTAL & $\mathbf{5 3 , 4}$ & $\mathbf{7 5 , 9 3}$ & $\mathbf{2 2}$ & \\
\hline & MEAN & & & \\
\hline
\end{tabular}

Rata-rata deviasi dalam experimental klas adalah 22 itu maksudnya bahwa deviasinya adalah tinggi . Kelas ini diajarkan dengan menggunakan model pembelajaran E-Learning

Table 4. Kalkulasi dari kelas kontrol 


\begin{tabular}{|c|l|c|c|c|c|}
\hline NO & $\begin{array}{l}\text { STUDENTS' } \\
\text { INITIAL NAME }\end{array}$ & $\begin{array}{c}\text { PRE- } \\
\text { TEST } \\
(\mathrm{y} 1)\end{array}$ & $\begin{array}{c}\text { POST- } \\
\text { TEST } \\
(\mathrm{y} 2)\end{array}$ & $\begin{array}{c}\text { DEVIATIO } \\
\text { N } \\
(\mathrm{d})\end{array}$ & $\begin{array}{c}\text { Square } \\
\text { Deviation } \\
(\mathrm{dy})^{2}\end{array}$ \\
\hline 1 & AFS & 50 & 55 & 5 & 25 \\
\hline 2 & ACMS & 60 & 66 & 6 & 36 \\
\hline 3 & AFWS & 45 & 53 & 8 & 64 \\
\hline 4 & BS & 43 & 48 & 14 & 196 \\
\hline 5 & CUP & 45 & 50 & 5 & 4 \\
\hline 6 & CAS & 42 & 52 & 10 & 25 \\
\hline 7 & DMN & 47 & 58 & 11 & 100 \\
\hline 8 & EDS & 40 & 45 & 5 & 25 \\
\hline 9 & EN & 45 & 62 & 7 & 49 \\
\hline 10 & EMN & 65 & 66 & 1 & 1 \\
\hline 11 & FEB & 60 & 65 & 5 & 1 \\
\hline 12 & FSB & 44 & 48 & 4 & 16 \\
\hline 13 & GJP & 45 & 51 & 6 & 36 \\
\hline 14 & HDW & 47 & 59 & 12 & 144 \\
\hline 15 & INS & $\mathbf{7 3 0}$ & $\mathbf{8 3 0}$ & $\mathbf{9 0}$ & \\
\hline 16 & JN & $\mathbf{4 8 , 6 6}$ & $\mathbf{5 5 , 3 3}$ & $\mathbf{6}$ & \\
\hline & TOTAL & & & & \\
\hline & MEAN & 66 & 25 & 12 \\
\hline
\end{tabular}

Rata -rata deviasai di dalam kelas kontrol adalah 6 itu berarti deviasinya rendah . group ini diajar tanpa menggunakan model pembelajaran E-Learning

\section{KESIMPULAN}

Berdasarkan pembahasan bab sebelumnya, penelitian ini dapat disimpulkan bahwa siswa kelas $\mathrm{V}$ SD Yabes School medan mengalami peningkatan hasil belajar bahasa Inggris dengan adanya model pembelajaran yang baru yang di terapkan oleh guru dalam mengajar bahasa Inggris dengan menerapkan model Pembelajaran E-Learning. Dapat dilihat dari hasil pre-test dan post-test dalam kontrol klas dan hasil dari pre-test dan post test dalam experimental klas, dari hasil tersebut dapat dilihat bahwa nilai dalam experimental klas lebih tinggi dari nilai kontrol klas. Dengan adanya penerapan model pembelajaran E-Leraning tersebut siswa dapat lebih aktif belajar dan dapat meningkatkan hasil belajar siswa. Di kelas experimental nilai yang terrendah di dalam pre-test adalah 35 dan yang tertinggi adalah 71 , sementara nilai yang terendah di dalam post-test adalah 63 dan nilai yang tertinggi adalah 88 . Nilai rata-rata dari pre-test adalah $(53,40)$ dan post test ( 76.00$)$. jadi deviasi adalah 22,6. Dari tabel 2 diatas 
dapat di lihat bahwa dalam kelas kontrol, skore yang terrendah dalam pre-test adalah 34 dan skor yang tertinggi adalah 72 . Sementara peningkatan rata-rata nilai dari pre test $(48,66)$ to post-test $(55.33)$

\section{DAFTAR PUSTAKA}

[1] Clark, R.C. \& Mayer, R.E. (2008). E-learning and the science of instruction: proven guidelines for consumers and designers of multimedia learning, second edition. San Francisco: John Wiley \& Sons, Inc.

[2] Firman \& Sari. (2020). Pembelajaran Online di Tengah Pandemi Covid-19. Indonesian Journal Of Educational Science (IJES), Volume 02 No 02.

[3] Kuo, et al. (2014). Interaction, Internet self- efficacy, and self-regulated learning as predictors of student satisfaction in online education courses. Volume 20, pages 35-50.

[4] Hasanah, dkk. (2020). Analisis Aktivitas Belajar Daring Mahasiswa Pada Pandemi COVID-19. Jurnal Pendidikan. Volume 1 No.1.

[5] Munir (2009). Pembelajaran jarak jauh ber basis teknologi informasi dan komunikasi. Bandung: Alfabeta.

[6] Seok, Soonhwa. (2008). The aspect of e- learning. International Journal on ELearning, Proquest, $7(4), 725-741$.

[7] Sugiyono. (2016). Metode Penelitian Kuantitatif, Kualitatif, dan R\&D. Bandung: Alfabeta. 